\title{
Інформаційна інаціональнабезпека
}

УДК 342.7:004

ЗОЛОТАР О.О., доктор юридччних наук, старший науковий співробітник, завідувач науковим сектором НДІ інформатики і права НАПрН України.

\section{ПОНЯТТЯ ТА ЗМІСТ КАТЕГОРЇ̈ “ІНФОРМАЦЙНА БЕЗПЕКА ЛЮДИНИ"}

Анотація. У статті аналізуються доктринальні підходи до визначення науковоі категорії “інформаційна безпека людини”, а також розуміння ї̈ змісту.

Ключові слова: інформачійна безпека людини, структура інформаџійної безпеки людини.

Summary. Doctrinal approaches to the definition of the scientific category of "Human Information Security", as well as understanding of its content, are analyzed.

Keywords: sociological research, electoral process, democracy, information influence.

Аннотация. В статье анализируются доктринальные подходы к определению научной категории “информационная безопасность человека", а также ее понимание.

Ключевые слова: Human Information Security, structure of Human Information Security.

Постановка проблеми. Розвиток науки про безпеку в напрямку інформаційної безпеки істотно залежить від стану формування інформаційного суспільства в конкретній державі. Рівень розвитку і використання інформаційно-комп'ютерних технологій (далі - IКТ) в світі дуже нерівномірний - наприклад, доступ до Інтернету має близько 60 \% жителів планети, при цьому найвищі показники більш 90 \% - в Південній Кореї та Австралії, і найнижчі - менше 10 \% - в деяких африканських країнах.

Це означає, що в залежності від рівня розвитку ІКТ, інформаційні проблеми населення суттєво відрізняються. Однак, це не означає, що вони не існують. Людина завжди “приречена" на пошук, оцінку і захист інформації (різниця полягає лише за своїм змістом - інформація про місця для полювання, джерела води, інше плем'я або про комерційну таємницю, авторські права і персональны даны), тобто, інформаційну діяльність, яка нерозривно пов'язана з інформаційною безпекою. Тільки ось за умови формування інформаційного суспільства значення останньої неухильно зростає.

Інформаційна діяльність сучасної людини є необхідною умовою її самореалізації та задоволення різноманітних потреб та інтересів - матеріальних, соціальних і духовних. Кількість і якість існуючої і доступної інформації, а також інтенсивність впливу інформаційного простору на людину абсолютно змінилася за останні півстоліття, в т.ч. в зв'язку 3 останньою інформаційною революцією - винаходом і повсюдним використанням інтернету. "Інтернет ...набагато більше схожий на інформаційну супермагістраль 3 пробками, ніж на інформацію" [1]. I в цьому величезному потоці інформації людина змушена не тільки лавірувати в цілях пошуку необхідної інформації, але також і захищати свої інтереси, зберігати і відстоювати свої цінності, а також протистояти негативному впливу і загрозам інформаційного простору.

Переважна кількість наукових досліджень категорії “інформаційна безпека" спрямована на вирішення питань, пов'язаних або з інформаційною безпекою держави, або 3 національною інформаційною безпекою, в яких проблематика інформаційної безпеки 
людини розглядається частково і виключно як складова ширшого об’єкта безпеки. Таким чином, інформаційна безпека людини, в цілому, є актуальним предметом досліджень не тільки правових наук, а й соціологічних та психологічних, а також теорії управління та науки про безпеку. Попри те, слід відзначити у всіх цих науках відсутність чіткої і загальновизнаної термінологічної системи у сфері інформаційної безпеки, що впливає на розбіжність у доктринальному та практичному тлумаченні цієї важливої категорії.

Метою статті $\epsilon$ дослідження наукових підходів до розуміння інформаційної безпеки людини і формулювання визначення цієї наукової категорії на основі іiї істотних складових.

Результати аналізу наукових публікацій. Інформаційна безпека як наукова категорія передбачає доктринальні, енциклопедичні та нормативно-правові визначення. При цьому методологічні підходи, логічні способи їх утворення і закріплення, сфери існування і прикладного використання істотно відрізняються. Це пов'язано також з тим, що категорія безпеки неоднозначна і визначається в залежності від наукової області, в якій вона вивчається.

В основі будь-якої безпеки як системи мають місце життєве важливі інтереси особистості, нації, держави або міжнародної спільноти. Так, Ярочкин В.І. визначає безпеку як стан захищеності особистості, суспільства i держави від зовнішніх i внутрішніх небезпек і загроз, заснована на діяльності людей, суспільства, держави, світового співтовариства щодо виявлення (вивчення), попередження, послаблення, ліквідації та відображенню небезпек i загроз, здатних їх знищити, позбавити фундаментальних матеріальних і духовних цінностей, завдати неприйнятної шкоди, закрити шлях для прогресивного розвитку [2, с. 253].

У цьому, як процесі, проявляється розуміння, сенс, необхідність усвідомленого оволодіння ідеєю безпечного існування заради подальшого існування або розвитку соціальної системи.

Розкриваючи філософські проблеми безпеки як соціального явища, слід зазначити, що поняття про безпеку і усвідомлення іï необхідності проявляється як на чуттєвому (підсвідомому), так i на раціональному рівні. У дослідженнях польський вчений К. Лідерман, стверджує, що в той час як забезпечення стосується більшою мірою заходів (технічних, організаційних, правових і т.д.), то безпека - суб'єктивного відчуття. Передчуття, негативні емоції, відчуття небезпеки, відчуття необхідності самозахисту 3 подальшим усвідомленим формуванням системи охорони і захисту є проявом багатства різноманітності людської природи, невичерпності людських якостей. Тобто, безпеку знаходить відображення в свідомості суб'єкта суспільних відносин як динамічний процес, який має ряд варіативних детермінант - стан, рівень розвитку системи, в тому числі культурності і цивілізованості. Тому обгрунтованою $є$ постановка проблеми виявлення і розкриття сутнісних ознак безпеки як соціального феномена. До таких можна віднести: усвідомлена самодостатність, здатність до самозбереження, захищеність від загроз, гарантованість власного існування і т.д. У практичній діяльності (в політичній, економічній, правовій, культурній сферах) мають місце статичні ознаки: визначення стану захищеності від загроз в просторі, часі та за колом осіб.

Російська вчена, одна 3 “піонерів" інформаційного права Бачило І.Л. акцентувала увагу на багатоплановості поняття “інформаційна безпека" [3, с. 253]. Більшість українських вчених, визначаючи інформаційну безпеку, розглядає іiі системно, наприклад, як “стан захищеності життєво важливих інтересів людини, суспільства i держави в інформаційній сфері від зовнішніх і внутрішніх викликів і загроз, який 
забезпечує їх сталий розвиток” [4, с. 150]. Подібну позицію підтримують Бєляков К.І. [5, с. 28], Баранов О.А. [6, с. 160], Довгань А.Д. [7, с. 165], Нижник Н.Р. [8, с. 45].

Петрик В.Н. відзначає, що природні явища “безпека" i “небезпека" існують в діалектичному взаємозалежності, тобто в природі не існує окремо “стану безпеки” i “стану небезпеки” [9, с. 25].

Богуш В. ставить акцент на інформаційне середовище суспільства і визначає, що “інформаційна безпека - це стан захищеності інформаційного середовища суспільства, що забезпечує його формування, використання i розвиток в інтересах громадян, організацій, держави" [10, с. 42].

Виклад основних положень. Більш розширений аналіз змісту категорії “безпека" дозволяє стверджувати, що в суспільній свідомості це поняття ототожнюється не стільки з об'єктивними ознаками - відсутністю загроз, скільки з суб'єктивними станом, почуттями і переживаннями людей [16]. I тому в тріаді “людина, держава, суспільство" небезпідставно на першому місці як об'єкт інформаційної безпеки має визначатися людина, в т.ч. реалізація їі конституційних прав на доступ до інформації, на використання інформації в інтересах здійснення не забороненої законом діяльності, фізичного, духовного та інтелектуального розвитку, а також захист інформації, що забезпечує особисту безпеку.

В останні десятиліття актуалізувалося питання захисту інформаційних прав i свобод людини в зв'язку з інтенсифікацією інформаційних процесів. I в науковому обігу, а також в окремих нормативно-правових актах, з'явилася як самостійна категорія “інформаційна безпека людини (особистості, особи)”. При цьому, як правило, категорії осіб, особистість і фізична особа як правило ототожнюються, коли мова йде про інформаційну безпеку.

Розглядаючи зміст інформаційної безпеки людини, слід звернути увагу на вже існуючі підходи. Так, наприклад, російський вчений Баринов С.В. розглядає такі аспекти інформаційної безпеки особистості як інформаційно-технічна безпека, інформаційно-ідеологічна безпека, інформаційно-психологічна безпека особистості, а також інформаційно-правова безпека особи [11].

Такий підхід значною мірою відображає сфери, в яких можуть бути реалізовані негативні інформаційні впливи - технологічна, психологічна (в складі якої може бути виділена ідеологічна, емоційна, сфера самоідентифікації і самореалізації, релігійна та ін.), Правова, економічна, соціальна (адаптаційна, етнокультурна, національна та ін.), екологічна та інші.

Галатенко В.А. визначає інформаційно-технічну безпеку, як “захищеність інформації і підтримуючої інфраструктури від випадкових або навмисних впливів природного або штучного характеру, що можуть призвести до завдання шкоди власникам або користувачам інформації і підтримуючої інфраструктури” [12, с. 39]. Не цілком згодні 3 таким визначенням, оскільки автор, називаючи цю складову “інформаційно-технічною” у визначенні описує “інформаційно-технологічну”.

Ковальова М.М., виділяє інформаційно-ідеологічну безпеку, як захищеність від навмисного або ненавмисного інформаційного впливу, в результаті якого порушуються права i свободи в області створення, споживання та поширення інформації, користування інформаційною інфраструктурою і ресурсами, що суперечить моральним $\mathrm{i}$ етичним нормам, який чинить деструктивний вплив на особистість, що має негласний (неусвідомлений) характер, що впроваджує в суспільну свідомість антисоціальні установки [13, с. 109]. Не вважаємо за доцільне розглядати інформаційно-ідеологічну 
безпеку як категорію, що стосується окремої особистості, оскільки, метою будь-якої ідеології є вплив на суспільство в цілому або окремі соціальні групи.

Більш обгрунтованим є підхід у пропозиціях Осторухова В.В., який пропонує розглядає інформаційно-психологічну безпеку особистості у вузькому і широкому розумінні. У першому випадку, на його думку, це стан захищеності психіки людини від негативного впливу, який здійснюється шляхом впровадження деструктивної інформації в свідомість і (або) в підсвідомість людини, що призводить до неадекватного сприйняття нею дійсності. У більш широкому розумінні, під інформаційно-психологічною безпекою особистості, він пропонує розуміти: по-перше, належний рівень теоретичної та практичної підготовки особистості, при якому досягається захищеність і реалізація іiі життєве важливих інтересів i гармонійний розвиток незалежно від наявності інформаційних загроз; по-друге, здатність держави створити умови для гармонійного розвитку і задоволення потреб особистості в інформації незалежно від наявності інформаційних загроз; по-третє, забезпечення, розвиток і використання інформаційного середовища в інтересах особистості; по-четверте, захищеність від різного роду інформаційних загроз [14, с. 456].

Грачов Г.В. також звертає увагу на багатофакторність категорії, визначаючи інформаційно-психологічну безпеку як “стан захищеності психіки від дії різноманітних інформаційних факторів, що перешкоджають чи ускладнюють формування i функціонування адекватної інформаційно-орієнтовної основи соціальної поведінки людини (і в цілому життєдіяльності в суспільстві), а також адекватної системи його суб'єктивних (особистісних, суб'єктивно-особистісних) відносин до навколишнього світу і самому собі" [15, с. 15$]$.

Лихачов С.В. вважає, що проблеми інформаційно-психологічної безпеки неможливо розглядати окремо від проблем розвитку суспільства, оскільки система забезпечення такої безпеки неможлива без визначення стратегій розвитку того чи іншого суспільства, без розробки відповідних моделей цивілізаційного розвитку, моделей розвитку культури [16, с. 106].

Важливим фактором інформаційно-психологічної безпеки особистості є та частина інформаційного середовища суспільства, яка неадекватно відображає навколишній світ. Тобто інформація, яка вводить людей в оману, в світ ілюзій, не дозволяє адекватно сприймати навколишній і самого себе [17, с. 543]. Наслідком такого сприйняття може стати неможливість ефективно брати участь в житті суспільства, реалізовувати свої права і виконувати обов'язки, починаючи від правового нігілізму і аж до злочинної діяльності. Виходячи 3 подібної точки зору російський дослідник Панарін І.М. робить більший акцент на ролі політичної еліти, яка може протистояти інформаційному впливу. На його думку, “інформаційна безпека - стан інформаційного середовища суспільства i політичної еліти, яка забезпечує їі формування та розвиток в інтересах керівництва країни, громадян і суспільства" [18, с. 9].

Враховуючи вищезазначене, вважаємо, що зміст інформаційної безпеки людини як наукової і правової категорії повинен грунтуватися на осмисленні комплексності цього соціального явища, а також враховувати інформаційні права і свободи людини, які $\epsilon$ змістовним наповненням, що визначає сутність даної категорії.

Наукове розуміння актуальності та комплексності проблеми інформаційної безпеки людини є необхідною умовою ㄲï правового та організаційного забезпечення. Не можемо не погодитись з Пилипчуком В.Г. і Брижко В.М., що “повага і неухильне забезпечення прав, свобод і безпеки людини - гарантія від несанкціонованого втручання у ії приватне життя та одна із головних функцій держави" [19, с. 61]. 3 метою ефективної державної 
політики інформаційної безпеки людини необхідно науково обгрунтувати правові способи збалансування інформаційних прав людини i необхідного державного втручання в інформаційні відносини.

\section{Висновки.}

Таким чином, виходячи з розуміння, що інформаційна безпека людини є складовою будь-якого виду інформаційної безпеки - чи то держави, чи суспільства, чи міжнародного співтовариства, а також має місце у складі інших сфер безпеки продовольчої, екологічної, економічної, соціальної тощо, а їі забезпечення є необхідною умовою реалізації прав і законних інтересів людини в кожній сфері їі життєдіяльності пропонуємо таке визначення цієї наукової категорії: “nid інформаційною безпекою людини слід розуміти стан і процес захищеності людини від інформаційних загроз $i$ викликів, щзо забезпечує можливість людини як біологічного організму $і$ сочіальної істоти функціонувати, розвиватись, задовольняти свої потреби і досягати бажаних для себе результатів в інформаційному суспільстві”.

Зміст інформаційної безпеки людини, на нашу думку, становлять інформаційні права і свободи людини, а в іiі структурі можна виділити інформаційно-психологічну, інформаційно-технологічну та інформаційно-правову складові.

\section{Використана література}

1. Карафано Д. Понимание социальных сетей и национальная безопасность / пер. с англ. Савина Л. URL: https://www.geopolitica.ru/article/ponimanie-socialnyh-setey-i-nacionalnaya-bezopa snost (дата звернення: 09.03.2021).

2. Ярочкин В.И. Секьюритология - наука о безопасности жизнедеятельности. Москва, 2000. C. 28.

3. Бачило И.Л. Информационное право: основы практической информатики. Москва, 2001. C. 253.

4. Дзьобань О.П., Пилипчук В.Г. Інформаційне насильство та безпека: світоглядноправові аспекти; за заг. ред. проф. В.Г. Пилипчука. Харків: Майдан, 2011. 244 с.

5. Бєляков К.І. Внутрішня безпека України і шляхи їі забезпечення: наук. вид. Київ: МНДЦ, 2005. С. 26-32.

6. Баранов А.А. Информационная безопасность и економические преобразования: мат. междунар. конф. Углубление рыночных реформ и стратегия экономического развития Украинь до 2010 года. Ч. 2. Т. 1. Киев, 1999. С. 160.

7. Довгань О.Д. Забезпечення інформаційної безпеки в контексті глобалізації: теоретикоправові та організаційні аспекти: монографія. Київ, 2015. 388 с.

8. Нижник Н.Р. Національна безпека України (методологічні аспекти, стан і тенденції розвитку): навч.посібн. Ірпінь, 2000. 304 с.

9. Забезпечення інформаційної безпеки держави: підручник / В.М. Петрик та ін.; за заг. ред. О.А. Семченка. Київ: Книжкова палата України, 2015. 665 с.

10. Богуш В., Юдин А. Информационная безопасность государства. Москва: “МК-Пресс", 2005. $432 \mathrm{c}$.

11. Баринов С.В. О правовом определении понятия “информационная безопасность личности”. Актуальные проблемы российского права. 2016. № 4 (65). URL: https://cyberlen inka.ru/article/n/o-pravovom-opredelenii-ponyatiya-informatsionnaya-bezopasnost-lichnosti (дата звернення: 01.03.2021).

12. Галатенко В.А. Информационная безопасность. Открытые системыл. 1996. № 1 (15). C. 38-43.

13. Ковалева Н.Н. Информационное право России: учеб. пособие. Москва: Дашков и Ко, 2007. C. 109. 
14. Інформаційна безпека (соціально-правові аспекти): підручник / В.В. Остроухов, В.М. Петрик, М.М. Присяжнюк та ін.; за заг. ред. Є.Д. Скулиша. Київ: КНТ, 2010. 776 с.

15. Грачев Г.В. Информационно-психологическая безопасность личности: состояние и возможности психологической защиты. Москва: Изд-во РАГС, 1998. С. 15.

16. Лихачов С.В. Информаційно-психологічна безпека як складова національної безпеки України. Науковий вісник Львівського державного університету внутрішніх справ. 2012. № 2(1). С. 103-108.

17. Политическая психология: учеб. пособие для вузов / Деркач А.А., Жуков В.И., Лаптев Л.Г. (ред.). Екатеринбург: Деловая книга, 2003. 858 с.

18. Панарин И.Н. Информационная безопасность. URL: http://panarin.com/ info_voina/86informacionnaya-bezopasnost.html. (дата звернення: 01.03.2021).

19. Пилипчук В.Г., Брижко В.М. Інформаційна безпека та приватність у сфері захисту персональних даних. Інформація $і$ право. № 4(19)/2016. С. 60-70.

$\sim * * * \sim \sim \sim \sim \sim \sim \sim \sim \sim \sim \sim \sim$ 